SOSIOLIUM

\title{
LITERASI SOCIOPRENEURSHIP DAN SUSTAINABLE LIFESTYLE PESERTA DIDIK SMP NEGERI 25 SEMARANG DI TENGAH COVID-19
}

\author{
Melati Ramadhania, Ferani Mulianingsih ${ }^{\bowtie}$ \\ Prodi Pendidikan IPS, Fakultas Ilmu Sosial, Universitas Negeri Semarang, Indonesia
}

\begin{tabular}{l}
\hline Info Artikel \\
\hline Sejarah Artikel: \\
Disubmit: Juli 2021 \\
Direvisi: Agustus 2021 \\
Diterima: September \\
2021 \\
\hline Keywords: \\
Literasi Sociopreneruship; \\
Sustainable Lifestyle; Peserta \\
Didik; Pandemi COVID- \\
19_
\end{tabular}

\begin{abstract}
Abstrak
SMP Negeri 25 Semarang mengembangkan kurikulum yang berbasis lingkungan supaya mengembangkan budaya sekolah yang peduli terhadap lingkungan hidup sekaligus mengajarkan anak berwirausaha. Tujuan penelitian ini adalah untuk mengetahui (1) untuk mengetahui tingkat sociopreneurship pada peserta didik di tengah pandemi COVID19 (2) sikap Sustainable Lifestyle yang dimiliki peserta didik di tengah pandemi COVID19. Metode penelitian ini adalah Kualitatif dengan teknik pengumpulan data observasi, wawancara, dokumentasi, dan perposive sampling. Lokasi penelitian di SMP Negeri 25 Semarang Teknik validitas data menggunakan triangulasi sumber. Hasil penelitian ini menunjukan bahwa (1), tingkat literasi sociopreneurship peserta didik kelas VII, VIII, IX SMP Negeri 25 Semarang di tengah pandemi COVID-19 menunjukkan kategori cukup (2) tingkat sustainable life style peserta didik SMP Negeri 25 Semarang di tengah pandemi COVID-19 menunjukkan kategori tinggi
\end{abstract}

\section{Abstract}

SMP Negeri 25 Semarang develops an environment-based curriculum in order to develop a school culture that cares about the environment while teaching children to be entrepreneurship. The purpose of this study was to find out (1) to determine the level of sociopreneurship in students in the midst of the COVID-19 pandemic (2) the Sustainable Lifestyle attitude possessed by students in the midst of the COVID-19 pandemic. This research method is qualitative with data collection techniques of observation, interviews, documentation, and perposive sampling. The research location is at SMP Negeri 25 Semarang. The data validity technique uses source triangulation. The results of this study indicate that (1) the level of sociopreneurship literacy of students in grades VII, VIII, IX of SMP Negeri 25 Semarang in the midst of the COVID-19 pandemic shows a sufficient category (2) the level of sustainable life style of students of SMP Negeri 25 Semarang in the midst of the COVID-19 pandemic. -19 indicates high category.

\footnotetext{
Alamat korespondensi:

Gedung C1 Lantai 1 FIS Unnes

Kampus Sekaran, Gunungpati, Semarang, 50229

E-mail: melati.rahmadhania@gmail.com
}

E-ISSN 2685-4929 


\section{PENDAHULUAN}

$\begin{array}{crr}\text { Berdasarkan data } & \text { dari } \\ \text { siagacorona.semarangkota.go.id } & \text { Pada }\end{array}$ September 2021 Sumber dari dinas kesehatan Kota Semarang Total kasus terkonfirmasi 87.841, kasus suspek warga Semarang 45, kasus probable 19 (total kematian probable 444). Sedangkan kasus terkonfirmasi dirawat 46, kasus sembuh 67.742 dan kasus meninggal 4.457. Data tersebut diambil dari Pusat Kesehatan Masyarakat (Puskemas), rumah sakit, dan tempat isolasi. Jumlah tersebut berdasarkan data yang dihimpun dari seluruh rumah sakit rujukan, puskesmas dan rumah isolasi Rumah Dinas (rumdin). Bulan Maret 2020 awal, Indonesia memulai perperangan untuk menghadapi coronavirus disease that was discovered in 2019 (COVID19) yang mulai masuk di Indonesia hingga saat ini. Tentunya dengan masuknya pertama kali COVID-19 di Indonesia akan memberikan dampak secara tidak langsung terhadap Perekonomian di Negara Indonesia.

Masa pandemi seperti ini Kurniawan (2018: 35) mengatakan bahwa sociopreneurship atau usaha berbasis kegiatan sosial menjadi solusi baru bagi masyarakat yang pertama kali memulai usaha baru maka dari itu hakikatnya manusia sebagai makhluk sosial, mereka harus saling membantu antara satu sama lain agar usaha mereka tetap berjalan sehingga mereka tetap bisa melaksanakan aktivitas sociopreneurshipnya. Fenomena ini bukan barang baru di era digital seperti sekarang, dengan kemudahaan akses teknologi dan informasi berbagai macam sociopreneurship mulai bermunculan di tengah masyarakat untuk menjawab permasalahan yang ada pemberdayaan masyarakat dalam mitigasi bencana umumnya dilakukan pelatihan-pelatihan, transfer pengetahuan serta pembekalan dalam menghadapi bencana.

Multikulturalisme yang ada di Indonesia menyebutkan bahwa Indonesia mempunyai banyak keragaman dan kekayaan hal tersebut dibuktikan oleh Prasetyo (2019) yang menyatakan bahwa kearifan lokal pada masyarakat tradisional di Indonesia merupakan alternatif dalam mencegah bencana ataupun dalam penanganan pasca bencana, sehingga kearifan lokal memiliki peran penting dalam memitigasi bencana yang terjadi di Indonesia. Sehingga Pemerintah dapat memanfaatkan nilainilai kearifan lokal sebagai langkah dalam mitigasi bencana di negara tesebut. Kerjasama, solidaritas, gotong royong, tanggung jawab, mengahragai orang lain, peduli sesama dan peduli lingkungan yang penting ditanamkan semenjak dini, yang pada intinya bertujuan mengembangkan sikap empati kepada orang lain sehingga akan membentuk gaya hidup berkelanjutan Gaya hidup yang sustainable atau yang disebut juga sustainable lifestyle merupakan upaya yang mendasarkan perilaku pada kehidupan yang berkelanjutan. Tidak hanya kesehatan dan pola hidup personal tetapi juga gaya dan pola hidup yang berkaitan dengan proses penjagaan kelestarian alam. Manfaat dari adanya sustainable lifestyle yaitu akan ada rasa saling tolong menolong antar sesama dan adanya rasa peduli terkadap kawan dan pelestarian lingkungan.

Sekolah sangat ideal melatih peserta didik untuk mengetahui Pengembangan Pendidikan Karakter dan Kewirausahaan (entrepreunership) yang telah dimulai sejak 2010, yaitu sejak diterbitkan Buku Pedoman Pendidikan Budaya dan Karakter Bangsa sebagai salah satu hasil dari program 100 hari yang diamanahkan kepada Badan Penelitian dan Pengembangan Kementerian Pendidikan Nasional Kabinet Bersatu II. Kementerian Pendidikan dan Kebudayaan (Kemendikbud) melanjutkan program Pendidikan Kecakapan Kerja (PKK) dan Pendidikan Kecakapan Wirausaha (PKW). Udin (2004: 1.26) mengatakan bahwa Kemampuan peserta didik untuk menyesuaikan diri terhadap lingkungan sekitar menjadi penting dalam pengembangan pengetahuan dan kompetensi sehingga mereka mampu menjalin hubungan dengan sesama dan peka terhadap lingkungan sekitar, Ilmu Pengetahuan Sosial (IPS) berfungsi sebagai ilmu pengetahuan untuk mengembangkan kemampuan dan sikap rasional tentang gejalagejala sosial serta kemampuan tentang perkembangan masyarakat Indonesia dan masyarakat dunia dimasa lampau dan masa kini. SMP Negeri 25 Semarang memiliki visi "BERPRESTASI DAN BERWAWASAN LINGKUNGAN YANG AMAN DAN NYAMAN BERDASARKAN IMTAQ". SMP Negeri 25 Semarang Mengembangkan kurikulum yang berbasis lingkungan, di tahun 2021 sekolah mengikuti lomba adiwiyata supaya Mengembangkan budaya sekolah yang peduli terhadap lingkungan hidup sekaligus mengajarkan anak berwirausaha melalui pengelolaan kolam ikan lele. SMP Negeri 25 Semarang juga mengadakan kegiatan kewirausahaan dan terdapat kantin kejujuran serta koperasi siswa namun karena adanya pandemi kegiatan kewirausahaan tersebut ditiadakan terlebih dahulu. sikap kepekaan yang 
tinggi terhadap lingkungan, hubungan antar guru dengan peserta didik maupun guru dengan guru dan staf sekolah di SMP Negeri 25 Semarang sangat penting keberadaannya dalam kehidupan di sekolah agar terjalin hubungan yang baik antara warga sekolah satu dengan yang lainnya sehingga terciptalah sustainable lifestyle apalagi di masa pandemi seperti ini namun disebabkan pandemi peserta didik yang belajar jarak jauh jadi sangat susah bagi guru untuk mengawasi mereka. Anak-anak mulai hilang kedisplinan, berdasarkan hasil pengamatan awal terdapat anak yang mulai menekuni peluang business oriflame namun mulai merambahnya bisnis online seperti ini membuat anak-anak tergiur untuk berperilaku konsumtif ditambah masa pandemi anak-anak bosan dirumah akhirnya mereka hanya mempunya hiburan smartphone akhirnya tak jarang dari mereka ketagihan game online.

literasi sociopreneurship dan sikap sustainable Lifestyle Sociopreneur di lingkungan pendidikan akan mengajarkan peserta didik menggunakan kemampuan entrepreneurship untuk bermanfaat bagi masyarakat sekitarnya, Pelaku sociopreneur akan melakukan perubahanperubahan sosial yang bermanfaat misalnya dalam kesejahteraan, pendidikan, dan kesehatan masyarakat. Iniliah entrepreneur yang cerdas dalam menyelesaikan masalah bangsa ini. Berdasarkan uraian di atas, maka artikel ini akan menguraikan mengenai dua hal, yang pertama yaitu mengenai tingkat sociopreneurship pada peserta didik dan sikap Sustainable Lifestyle yang dimiliki peserta didik, konsep lifestyle lebih menunjukkan bagaimana peserta didik hidup, bagaimana menghabiskan uangnya dan bagaimana mengalokasikan waktunya.

\section{METODE}

Data dalam tulisan ini diperoleh melalui observasi, wawancara, dan dokumentasi. Penelitian ini dilaksanakan di salah satu SMP yang ada di Semarang yaitu SMP Negeri 25 Semarang terletak di J1. Kualamas, Tanahmas, Kec. Semarang Utara, Kota Semarang, Jawa Tengah 50177. Validitas data dicapai dengan teknik triangulasi sumber.

\section{HASIL DAN PEMBAHASAN}

\section{Seting Lokasi Penelitian}

SMP Negeri 25 Semarang yang ada di J1. Kualamas, Tanah Mas Semarang. Jika dilihat dari titik koordinat SMP Negeri 25 Semarang berada pada $6^{\circ} 57^{\prime} 29.5^{\prime \prime S} 110^{\circ} 24^{\prime} 04.9^{\prime \prime} \mathrm{E}$ (6.958184, 110.401365). Jarak SMP Negeri 25
Semarang untuk sampai ke pusat pemerintahan kota yaitu kurang lebih $8,1 \mathrm{Km}$ dengan waktu tempuh lima belas menit baik menggunakan kendaraan roda dua maupun empat.

Guru dan siswa di SMP Negeri 25 Semarang jumlahnya cukup banyak. Jumlah guru sebanyak 36 orang serta 7 karyawan dan jumlah siswa sebanyak 755 anak. Jenis bangunan yang mengelilingi sekolah a) Sebelah selatan : Sebelah selatan dari SMPN 25 Semarang terdapat jalan raya Kokrosono dan lingkungan SMAN 14 Semarang. b) Sebelah barat: Sebelah barat dari SMPN 25 Semarang terdapat mushola dan sepanjang jalan arteri. c) Sebelah timur: Sebelah timur dari SMPN 25 Semarang terdapat jalan Kuala Mas II, dan lingkungan SMAN 14 Semarang. d) Sebelah utara: Sebelah utara dari SMPN 25 Semarang terdapat perumahan warga.

SMP Negeri 25 Semarang memiliki 2 basis. Berbasis lingkungan sosial dan lingkungan fisik adiwiyata. Jadi tim kurikulum membuat kurikulum bagaimana semua RPP berbasis lingkungan sosial dan lingkungan fisik artinya ramah anak dan ramah lingkungan tetapi tetap minimal dikaitkan ke pendidikan. Sekolah mengikuti adiwiyata yaitu bahwa memang diperintahkan saat itu oleh kementrian pendidikan supaya sekolah memang harus mengembangkan kurikulum berbasis lingkungan, SMP Negeri 25 Semarang di tata sesuai dengan kriteria adiwiyata dan perilaku anak-anaknya. Supaya anak-anak membiasakan diri dan menyadari kemudian mengharuskan kita untuk menjaga lingkungan karena menyadari bahwa lingkungan merupakan sumber kehidupan selama ini dan untuk kedepannya harus asri, hijau, dan lain sebagainya. Serta mewujudkan sekolah ramah anak yang berarti program untuk mewujudkan kondisi aman, bersih, sehat, peduli, dan berbudaya lingkungan hidup, yang mampu menjamin pemenuhan hak dan perlindungan anak dari kekerasan, diskriminasi, dan perlakuan salah lainnya, selama anak berada di SMP Negeri 25 Semarang.

\section{Sejarah SMP Negeri 25 Semarang}

SMP NEGERI 25 Semarang berdiri pada tanggal 20 Nopember tahun 1984. SK Menteri Pendidikan dan Kebudayaan No. 0557/0/1984 tentang Pembukaan, Penunggalan dan Penegerian Sekolah Menengah Umum Tingkat Pertama. Pada saat pertama berdiri ada 3 ( tiga ) kelas dengan Kepala Sekolah Bapak Drs. Bagaswara, karena belum memiliki gedung sendiri maka untuk melaksanakan proses Kegiatan Belajar Mengajar menempati gedung SD Panggung IV , Jl. Delta Mas, Tanahmas 
Semarang masuk sore. Pada tahun kedua pindah ke SLTP Hasanudin Semarang di Jalan Gondomono Semarang dikarenakan SD Panggung IV tidak menampung semua siswa dan waktu itu Kepala Sekolah Bapak MM. Kismono Reksobowo, BSc. Yang sebelumnya menjabat Kepala Sekolah SLTP Negeri Banjaratma, Pemalang. Pada tahun ketiga SLTP Negeri 25 Semarang sudah dapat menempati gedung sendiri di Jalan Kualamas, Tanahmas, Semarang dengan (3 ruang kelas, 1 ruang Guru, 1 ruang Tata Usaha, 1 Ruang Kepala sekolah, dan 1 Ruang BP.) Untuk kelancaran proses Kegiatan Belajar Mengajar maka Ruang Laboratorium, Ruang Guru dan Ruang Perpustakaan dijadikan Ruang Kelas. Siswa dibagi menjadi dua kelas pagi dan kelas sore.

Setelah berjalan beberapa tahun ada tambahan gedung sehingga siswa dapat masuk pagi semua dan mulai tanggal 26 Desember 1991 Kepala Sekolah dipimpin oleh Bu Bernadette Suherjati,BA sampai dengan Bulan Juli 1999. Dan pada tahun 1999 sampai dengan bulan September 2002 sebagai Kepala Sekolah dipimpin oleh Bapak Drs. Sukirman,SPd,SH, MM. Dengan jumlah keseluruhan siswa 600 anak yang dibagi menjadi dengan tiap tingkat ada lima kelas dan tiap kelas ada 40 anak. Pada Bulan September 2002 sampai dengan sekarang Kepala Sekolah dipimpin oleh Bapak Drs. Kardi dengan siswa 629 anak yang dibagi menjadi 16 ruang kelas ( Kelas I = 6 kelas, Kelas II = 5 kelas, dan Kelas III = 5 kelas). Pada Bulan November 2005 sampai dengan tgl 14 November 2009 Kepala Sekolah dipimpin oleh Bapak Drs. Hariyanto Dwiyantoro,MM. Dengan siswa 735 siswa yang dibagi menjadi 20 kelas. ( Kelas VII $=6$ kelas, Kelas VIII = 7 kelas, dan Kelas IX $=7$ kelas). Pada Bulan November 2009 sampai dengan Oktober2012 dipimpin oleh Kepala Sekolah Ibu Dra. Erna Kursistiningsih Rahayu,M.M. dengan siswa 720 siswa dengan jumlah kelas 20 kelas ( Kelas VII $=7$ kelas, Kelas VIII $=6$ kelas, dan Kelas IX =7 kelas). Pada Bulan Oktober 2012 sampai dengan Febuari 2014 dipimpin oleh Kepala Sekolah oleh Ibu Dra. Dwi Laswijati, M.M. Kons. dengan siswa 716 siswa dengan jumlah kelas 24 kelas ( Kelas VII $=8$ kelas, Kelas VIII $=8$ kelas, dan Kelas IX $=8$ kelas). Pada Bulan Pebruari 2014 sampai dengan bulan Oktober 2014 dipimpin oleh Kepala Sekolah Bapak Drs. H. Nusantara, M.M. dengan siswa 738 siswa dengan jumlah kelas 24 kelas ( Kelas VII $=8$ kelas, Kelas VIII $=8$ kelas, dan Kelas IX $=8$ kelas). Pada Bulan Oktober 2014 sampai dengan Oktober 2019 dipimpin oleh Kepala Sekolah Bapak Agung Nugroho, S.Pd dengan siswa 782 siswa dengan jumlah kelas 24 kelas ( Kelas VII $=8$ kelas, Kelas VIII $=8$ kelas, dan Kelas IX $=8$ kelas). Pada Bulan tanggal 21 Oktober 2019 sampai dengan sekarang dipimpin oleh Kepala Sekolah Ibu Dra. Anny Winarsih, M.Pd. dengan siswa 783 siswa dengan jumlah kelas 24 kelas $($ Kelas VII $=8$ kelas, Kelas VIII = 8 kelas, dan Kelas IX $=8$ kelas).

\section{Kegiatan Pembelajaran IPS (Ilmu Pengetahuan Sosial) Pada Materi Tentang Kewirausahaan SMP Negeri 25 Semarang}

Proses pembelajaran IPS dalam pendidikan memegang peranan penting untuk menambah ilmu pengetahuan terutama keterampilan berwirausaha dan juga penerapan konsep ke diri sendiri. Peran guru sebagai fasilisator tersebut maka guru IPS di SMP Negeri 25 Semarang dituntut untuk menciptakan proses pembelajaran yang menyenangkan yang dapat menarik minat peserta didik untuk mewujudkan tujuan pembelajaran, sehingga peserta didik mampu memberikan respon atau partisipasi mereka dalam proses pembelajaran tersebut. Seringkali peserta didik pada masa pembelajaran daring mereka kurang aktif pada saat di whatsapp grup hanya beberapa anak yang aktif dan kurangnya partisipati anak-anak bahkan banyak yang asyik ngobrol sendiri pada saat zoom meeting berlangsung padahal zoom meeting dilakukan hanya sebulan sekali mengingat borosnya penggunaan kuota.

\section{Literasi Sociopreneurship Pada Peserta Didik SMP Negeri 25 Semarang Di Tengah Pandemi COVID-19}

Para orang tua berkomitmen untuk mengatur waktu mereka sendiri di rumah untuk dapat menyisihkan waktu lebih banyak untuk menemani dan berinteraksi dengan anak. Misalnya selain beraktivitas kerja juga mendampingi anak saat belajar ataupun mengajar anak tentang berbagai hal seperti terkait literasi dan numerasi melalui berbagai kegiatan sehari-hari. Beberapa contoh kegiatan yang dapat membangun interaksi lebih produktif dengan anak misalnya anak diminta untuk belanja sesuatu. Melalui kegiatan ini, anak diajarkan menulis dan membaca daftar belanjaan yang harus dibeli, dan mengetahui proses berhitung. Berapa jumlah yang yang dibawa, berapa yang dibelanjakan. Berapa barang yang dibeli dan menghitung berapa sisa uang (jika ada) dan seterusnya. Atau bisa juga menulis dan membaca resep kue sebelum membuat kue. Menemukan solusi sederhana dan praktis juga berhasil ditemukan oleh orang tua. 
Pendidikan kewirausahaan bertujuan untuk membentuk manusia secara utuh (holistik), sebagai insan yang memiliki karakter, pemahaman dan ketrampilan sebagai wirausaha. Pada dasarnya, pendidikan kewirausahaan dapat diimplementasikan secara terpadu dengan kegiatan-kegiatan pendidikan di sekolah. Sampai saat ini konsep kewirausahaan masih terus berkembang salah satunya istilah tentang Sociopreneurship. Kewirausahan Sosial adalah suatu sikap, jiwa dan kemampuan untuk menciptakan sesuatu yang baru yang sangat bernilai dan berguna bagi dirinya dan orang lain. Di SMP Negeri 25 Semarang Pendidikan kewirausahaan diterapkan melalui pengembangan kurikulum adiwiyata dengan cara mengidentifikasi jenis-jenis kegiatan di sekolah yang dapat merealisasikan pendidikan kewirausahaan dan direalisasikan peserta didik dalam kehidupan sehari-hari dan diupayakan untuk menjadikan SMP Negeri 25 Semarang sebagai sekolah adiwiyata yang peduli akan lingkungan hidup. Dalam hal ini, program pendidikan kewirausahaan di SMP Negeri 25 Semarang dapat diinternalisasikan melalui berbagai aspek. Dengan diadakannya pendidikan kewirausahaan diharapkan peserta didik dapat menambah pengetahuannya tentang sociopreneurship serta dapat merealisasikan di kehidupan nyata di dalam lingkungan sekolah maupun di lingkungan rumah mereka masingmasing

Dari hasil penelitian kelas VII, VIII, IX terkait literasi sociopreneurship tentang aspek pengetahuan dan kompetensi diperoleh secara keseluruhan masuk kategori sebagai berikut:

\section{Pengetahuan}

Pengetahuan literasi sociopreneurship peserta didik SMP Negeri 25 Semarang di tengah pandemi covid-19 tentang aspek pengetahuan menunjukkan kategori cukup hal ini dipengaruhi oleh faktor internal dari pendidikan formal dan umur serta faktor ekternal dari lingkungan luar. Pendidikan di SMP Neegri 25 Semarang sangat diperlukan untuk mendapatkan informasi berupa hal-hal yang menjaga kesehatan pada masa pandemi covid-19. Dari usia peserta didik pengetahuan mereka berbeda-beda tergantung umur dan juga pengalaman mereka selama bersekolah dan menerima informasi dari pembelajaran maka semakin cukup umur, tingkat kematangan dan kekuatan peserta didik ini akan lebih matangd alam berfikir. Lingkungan peserta didik SMP Negeri 25 Semarang sangat berpengaruh apalagi lingkungan keluarga dan lingkungan sosial mereka seluruh kondisi yang ada sekitar peserta didik dan pengaruhnya dapat mempengaruhi perkembangan dan perilaku mereka.

\section{Kompetensi}

Kompetensi sangat diperlukan dalam setiap proses pembelajaran IPS untuk menentukan perangkat pembelajaran di setiap materi yang akan di ajarkan kepada peserta didik di SMP Negeri 25 Semarang. Pengetahuan literasi sociopreneurship peserta didik SMP Negeri 25 Semarang di tengah pandemi covid-19 tentang aspek kompetensi menunjukkan kategori cukup, Berdasarkan informasi yang peneliti dapatkan bahwa kompetensi peserta didik SMP Negeri 25 Semarang merupakan landasan dasar karakteristik mereka sehingga mengindikasikan cara berperilaku atau berpikir, menyamakan situasi, dan mendukung pembelajaran untuk periode waktu cukup lama. terdapat beberapa faktor yang dapat mempengaruhi kecakapan kompetensi peserta didik antara lain: keyakinan, keerampilan, pengalaman, karakteristik pribadi, motivasi pribadi, emosional, budaya organisasi. Dari berbagai fakor yang mempengaruhi kompetensi peserta didik SMP Negeri 25 Semarang diatas dapat dirumuskan bahwa kompetensi merupakan kemampuan menjalankan tugas atau pekerjaan dengan dilandasi pengetahuan, keterampilan, dan didukung oleh sikap yang menjadi karakteristik peserta didik kelas VII, VIII, dan IX SMP Negeri 25 Semarang.

SMP Negeri 25 Semarang belum begitu bisa menerapkan sociopreneurship hal ini dibuktikan dengan rendahnya pengetahuan tentang sociopreneurship dikalangan guru karena SMP baru ikut program adiwiyata tahun ini namun tetap Kepala Sekolah mengembangkan kewirausahaannya bertahap contoh mengolah sampah dari pohon menjadi kompos kemudian di kemas dan di jual sehingga uangnya dapat digunakan untuk membeli cabai atau bibit tanaman yang lain.

\section{Sikap sustainable lifestyle yang dimiliki peserta didik SMP Negeri 25 Semarang di tengah pandemi COVID-19}

Gaya hidup berkelajutan secara tidak sengaja banyak tampak di tengah anak-anak. Gaya hidup sederhana, hemat, tidak mubazir, bersih, suka menanam dan lain sebagainya adalah tampilan masyarakat yang sebagian sudah menjadi kebiasaan. Dengan kata lain perilaku ramah lingkungan yang diimplementasikan dalam kehidupannya sehari-hari bukanlah hasil pembelajaran atau anjuran dari pemerintah tetapi merupakan bawaan atau kebiasaan yang sudah terpatri membangun karakter dalam diri 
seseorang. Sebenarnya menurut sebagian besar informan penellitian, seseorang itu tampak dari hasil binaan keluarganya. Kadang-kadang ada yang mendahulukan kebiasaan orang tua dan ada pula yang mendahulukan agama. Tapi kalau ditanya tentang bagaimana hidup seseorang dalam lingkungannya maka yang tampak pasti agama dan kebiasaan turun-temurun dari keluarga yang sudah ada sejak dulu kala. Gaya hidup berkelanjutan ataupun yang sering disebut dengan gaya hidup berbasis lingkungan mereka dapatkan dari gaya hidup ataupun pola hidup orag tua mereka. Apabila mencari suatu kesenangan sebagai tujuan yang utama, maka orang-orang tersebut tidak akan punya empati kepada orang lain karena yang dipikirkannya hanya untuk memenuhi kesenangan pribadinya saja. Gaya hidup konsumtif membuat silau mata siapapun yang melihatnya

Dari hasil penelitian kelas VII, VIII, IX terkait tingkat sustainable lifestyle tentang aspek kerjasama, solidaritas, gotong royong, tanggung jawab, menghargai orang lain, peduli sesama, menghargai lingkungan diperoleh secara keseluruhan masuk katagori sebagai berikut:

\section{Kerjasama}

Sikap Sustainable Life Style peserta didik SMP Negeri 25 Semarang di tengah pandemi covid-19 tentang aspek kerjasama menunjukkan kategori rendah, Dengan bekerjasama kelompok kecil akan mampu mengatasi berbagai bentuk rintangan, bertindak mandiri dan dengan penuh rasa tanggunng jawab, mengandalkan bakat atau pemikiran setiap anggota kelompok, mempercayai orang lain, mengeluarkan pendapat dan mengambil keputusan. Namun sesuai dengan penelitian didapatkan bahwa sikap kerjasama SMP Negeri 25 Semarang rendah karena banyak dari mereka yang tidak kenal dengan temannya satu sama lain semenjak pembelajaran di rumah. Setiap peserta didik SMP Negeri 25 Semarang harus berlatih untuk berkomunikasi satu sama lain dalam kelompok agar setiap siswa dapat mengerti dan memahami materi pelajaran yang dipelajari dalam proses belajar kemudian peserta didik dituntut agar saling menghargai antar satu sama lain, tidak terbatas oleh peringkat kelas rendah, sedang atau pun tinggi. Jadi dalam kelompok itu peserta didik yang memiliki tingkat kecerdasan yang lebih dari teman-temannya harus mau membantu menjelaskan materi yang telah dipaparkan oleh guru kepada temannya yang kurang cerdas agar dapat mengerti materi pelajaran. Dengan seperti itu semua siswa dapat mengerti meteri ynag dijelaskan oleh guru.

\section{Solidaritas}

Di lingkungan SMP Negeri 25 Semarang dapat merasakan adanya rasa solidaritas yang tinggi atau kebersamaan banyak sekali kebersamaan yang tercipta. Kebersamaan dalam hal baik maupun hal buruk misalkan para pelajar yang terlibat contek mencontek saat ujian mereka mengatakan bahwa mereka mempunyai rasa solidaritas yang tinngi jadi bila temannya ikut mencontek maka pelajar yang lain juga harus ikut mencontek maupun memberikan jawabannya inilah salah satu contoh sikap solidaritas yang sangat buruk yang terjadi dan menimpa para pelajar di SMP Neegri 25 Semarang dan peneliti rasa tidak hanya pelajar di SMP Neegri 25 Semarag saja namun sudah berdarah daging di Indonesia, seharusnya rasa solidaritas di gunakan untuk hal-hal yang baik misalkan dalam wawancara dengan anak kelas IXD mengatakan bahwa pernah membantu jual dagangan temennya lalu belajar bersama ataupun berqurban.

\section{Gotong Royong}

Contoh kegiatan di SMP Neegri 25 Semarang yang dapat dilakukan secara bergotong royong antara lain pembangunan fasilitas dan membersihkan lingkungan sekitar, dan bersama sama mewujudkan sekolah adiwiyata. Sikap gotong royong keluarga SMP Negeri 25 Semarang termasuk dalam kategori tingggi dan dimiliki seluruh elemen atau lapisan dari mulai kepala sekolah, guru, karyawan, peserta didik dan orang tua wali murid yang bersekolah di SMP Negeri 25 Semarang. Karena dengan adanya kesadaran setiap elemen atau lapisan tersebut melakukan kegiatan dengan cara bergotong royong dengan demikian segala sesuatu yang akan dikerjakan dapat lebih mudah dan cepat diselesaikan dan pastinya tujuan visi misi dari SMP Negeri 25 Semarang akan semakin lancar dan maju. Bukan itu saja, tetapi dengan adanya kesadaran setiap elemen dan lapisan keluarga SMP Negeri 25 Semarang dalam menerapkan perilaku gotong royong maka hubungan persaudaraan atau silaturahmi akan semakin erat dan dapat mencontohkan ke masyarakat lain.

\section{Tanggung Jawab}

Tanggung jawab bersifat kodrati, sifat yang telah menjadi bagian atau telah mendasar dalam diri atau kehidupan manusia. Setiap individu memiliki sifat ini. Ia akan selalu ada dalam diri manusia karena pada dasarnya setiap insan tidak bisa melepaskan diri dari kehidupan sekitar yang menunutut kepedulian dan tanggung jawab. Inilah yang menyebabkan frekuensi tanggung jawab peserta didik SMP Negeri 25 
Semarang masuk kategori tinggi. Rasa tanggung jawab ialah sifat yang harus dimiliki oleh setiap orang karena dengan sifat ini banyak sekali manfaat yang dapat peroleh. Oleh karena itu, sebagai manusia kita harus bias menjadi seseorang yang bertanggung jawab atas semua yang dilakukan.

\section{Menghargai Orang Lain}

Dalam kehidupan sehari-hari tentunya kita sangat ingin dihargai oleh seseorang baik disekolah, dirumah, dan dimanapun kita berada. Menghormati dan menghargai orang lain harus dilakukan tanpa memandang derajat, status, warna kulit, atau pekerjaan orang tersebut karena menghargai orang lain merupakan pencerminan dari pribadi seseorang. Di SMP Negeri 25 Semarang menganjurkan agar saling menghargai antara satu sama lain dari mulai Kepala sekolah, gutu, karyawan dan peserta didik. Sikap menghargai terhadap orang lain tentu didasari oleh jiwa yang santun yang dapat menumbuhkan sikap menghargai orang di luar dirinya. Kemampuan tersebut harus dilatih lebih dahulu untuk mendidik jiwa manusia sehingga mampu bersikap penyantun. Peserta didik SMP Negeri 25 Semarang mereka beda-beda kepribadian talenta dan kebiasaan hidup misal contohnya pada kelas VII dan IX persentase tingkat sikap sustainable life style pada aspek menghargai orang lain termasuk dalam kategori tinggi sedangkan kelas VIII termasuk kategori rendah namun bisa saja sikap kelas VII dalam hal lainnya lebih unggul dibandingkan dengan tingkatan kakak kelas atau adeknya hal ini yang menjadi saling melengkapi.

\section{Peduli Sesama}

Kepedulian terhadap sesama peserta didik SMP Negeri 25 Semarang termasuk dalam kategori tinggi hal ini dibuktikan dengan perhatian terhadap situasi orang lain. salah satunya dengan menjengguk orang yang sakit. Dengan begitu salah satu contohnya Menjenguk orang sakit merupakan manifestasi (wujud) persaudaraan yang sangat mulia. Karena itu Harapannya di SMP Neegri 25 Semarang peserta didik mempunyai karakter terutama karakter peduli terhadap sesama, dan bisa menanamkannya.

\section{Menghargai Lingkungan}

Peserta Didik SMP Neegri 25 Semarang tidak hanya dapat menyesuaikan diri. Akan tetapi, dapat juga dapat memanfaatkan potensi lingkungan untuk lebih mengembangkan kualitas kehidupannya. Bagi peserta didik kelas VIII yang memiliki presentasi peduli terhadap lingkungan rendah akan menjadi terbiasa apabila merasakan kebermanfaatan lingkungan sekitar SMP Negeri
25 Semarang diantaranya dapat sebagai mempercantik sekolah dan tempat meneduh dan bersantai untuk belajar di alam bagi peserta didik, selain sebagai tempat tinggalnya, lingkungan hidup juga dapat dimanfaatkan.

Dengan mengerti dan memahami sikap peserta didik di SMP Negeri 25 Semarang maka guru akan lebih mudah mengajarkan empati kepada anak. Berempati dalam masa pandemi merupakan suatu hal yang penting. Agar merasa lebih nyaman dan disayang, ada baiknya menyampaikan sesuatu dengan nada yang lembut dan nyaman ketika memberi anak arahan. Terapkan dengan penuh kasih sayang dan kelembutan dengan begitu Peserta Disik sebagai Role Model atau sebagai panutan (tentang kelakukan, perbuatan, sifat, dan sebagainya).

\section{SIMPULAN}

Tingkat literasi sociopreneurship peserta didik kelas VII, VIII, IX SMP Negeri 25 Semarang di tengah pandemi COVID-19 menunjukkan kategori cukup hal ini ditunjang dengan beberapa aspek yaitu dari segi pengetahuan dan kompetensi dengan hal ini SMP Negeri 25 Semarang sangat ideal melatih peserta didik Pendidikan Kecakapan Kerja (PKK) dan Pendidikan Kecakapan Wirausaha (PKW) untuk lebih meningkatkan literasi sociopreneurship supaya lebih memahami dan mengetahui tentang sociopreneurship dengan begitu Peserta Disik sebagai Role Model atau sebagai panutan (tentang kelakukan, perbuatan, sifat, dan sebagainya) maka dari itu sociopreneurship merupakan bentuk penggabungan antara konsep kewirausahaan yang mengedepankan pada kegiatan ekonomi namun tujuan yang dicapai tidak hanya berorientasi pada profit, melainkan juga pada tujuan sosial. Tingkat sustainable life style peserta didik SMP Negeri 25 Semarang di tengah pandemi COVID-19 menunjukkan kategori tinggi hal ini ditunjang dengan beberapa aspek yaitu dari segi kerjasama, solidaritas, gotong royong, tanggung jawab, menghargai orang lain, peduli sesama, dan peduli lingkungan dengan hal ini peserta didik paham bahwa manusia tidak bisa hidup sendiri karena membutuhkan makhluk lainnya, tidak terkecuali tumbuhan dan hewan untuk lebih lanjutnya arahan guru dan orang tua sangat dibutuhkan anak dalam perkembangannya itu semua sesekali perlu dibicarakan dengan anak agar bisa memberi pemahaman yang benar. Setelah itu akan lebih mudah mengajarkan empati kepada anak. Berempati dalam masa pandemi COVID-19 merupakan suatu hal yang penting. 


\section{DAFTAR PUSTAKA}

Arikunto, Suharsimi. 2006. Definisi Operasional. Jakarta: Rineka Cipta.

Kurniawan. 2018. Sociopreneurship Atau Usaha Berbasis Kegiatan Sosial. Bandung: Sinar Baru

Prasetyo, B. 2019. Kearifan Lokal sebagai Basis Mitigasi Bencana. Seminar Nasional FST-UT Halaman 111-129.
Bogdan. 2013. Teknik Analisis Data Non probability Sampling. Bandung: Alfabeta.

Siagacorona.semarangkota.go.id. 2021. Tentang "Data Terkonfirmasi COVID-19 Kabupaten Semarang"

Udin. 2004. Kemampuan Peserta Didik Untuk Menyesuaikan Diri Terhadap Lingkungan Sekitar. Jakarta: Gramedia 